\title{
Effect of feeding different carbohydrate to lipid ratios on the growth performance and body composition of Nile Tilapia (Oreochromis niloticus) fingerlings ${ }^{1}$
}

\author{
Amanat Ali*, Nasser A. Al-AsgaH \\ Zoology Department, College of Science, King Saud University, PO Box 2455, \\ Riyadh 11451, Saudi Arabia
}

(Received 14 June 1999; accepted 12 October 2000)

\begin{abstract}
In this study, we evaluated the growth performance and body composition of Nile tilapia (Oreochromis niloticus) fed five isonitrogenous and isoenergetic diets (A, B, C, D and E) containing varying levels of carbohydrates $(18.27-40.37 \%)$ and lipids $(8.14-19.53 \%)$ with carbohydrate-to-lipid (CHO/LIP) ratios ranging from 4.95 to 0.94 . Significant $(P<0.05)$ differences were observed in the body weight gain, condition factor, specific growth rate (SGR), feed conversion ratio (FCR), protein efficiency ratio (PER), net protein retention (NPR) and apparent net energy retention (ANER) values of fish fed diets with different $\mathrm{CHO} / \mathrm{LIP}$ ratios. The $\mathrm{A}, \mathrm{B}$ and $\mathrm{C}$ diets with $\mathrm{CHO} / \mathrm{LIP}$ ratios ranging from 4.95 to $2.06 \mathrm{did}$ not result in any difference $(P>0.05)$ in fish performance. Decreasing the CHO/LIP ratio to 1.38 (diet D) significantly $(P<0.05)$ reduced growth rate and feed efficiency. A further decrease in the CHO/LIP ratio to 0.94 (diet E), however, did not affect $(P>0.05)$ these values any more. The hepatosomatic index (HSI) increased with a decrease in the $\mathrm{CHO} / \mathrm{LIP}$ ratio and was the highest (1.81) with a CHO/LIP ratio of 0.94 and lowest (1.33) with a $\mathrm{CHO} / \mathrm{LIP}$ ratio of 4.95 . No significant $(P>0.05)$ differences were observed in the HSI values between the fish fed diets $\mathrm{B}, \mathrm{C}$ and $\mathrm{D}$ with $\mathrm{CHO} / \mathrm{LIP}$ ratios ranging from 3.33 to 1.38 . The body compositions of the fish were significantly affected $(P<0.05)$ by different $\mathrm{CHO} / \mathrm{LIP}$ ratios in the diets. Body moisture and crude protein contents decreased whereas fat and ash contents increased with decreasing $\mathrm{CHO} / \mathrm{LIP}$ ratios. The $\mathrm{CHO} / \mathrm{LIP}$ ratio in the diets did not, however, affect $(P>0.05)$ the gross energy content of the fish. The results of the present study indicate that the optimal dietary CHO/LIP ratio for a maximum growth performance of Oreochromis niloticus ranges between 2.06 and 4.95 .
\end{abstract}

Oreochromis niloticus / carbohydrate to lipid ratio / feeding / growth / body composition

\footnotetext{
${ }^{1}$ Dedicated to Prof. Dr. Wilhelm Hartfiel on his 75 th birthday.

* Correspondence and reprints

Tel.: (416) 289 2107; fax: (416) 289 6606; e-mail: amanata @ hotmail.com; URL: www.geocities. com/bionutriag

Present address: BioNutriAg Consultant, 567 Scarborough Golf Club Road, \#1611, Toronto, Ontario, Canada M1G 1H5.
} 
Résumé - Effets de divers régimes alimentaires à base de glucides et de lipides sur la croissance et la composition corporelle du Tilapia (Oreochromis niloticus) fingerling. Cette étude avait pour but d'évaluer les performances de croissance et la composition corporelle du Tilapia (Oreochromis niloticus) alimenté avec différents régimes isoazotés et isoénergétiques (A, B, C, D, et E) contenant 18,27 à 40,37 \% de glucides (CHO) et 8,14 à 19,53\% de lipides (LIP), dans des proportions CHO/LIP variant de 4,95 à 0,94 . Des différences significatives $(P<0,05)$ ont été observées sur les valeurs de gain de poids corporel, de coefficient de condition (k), de taux de croissance spécifique (SGR), d'indice de consommation (FCR), de coefficient d'efficacité protéique (PER), de rétention protéique nette (NPR) et de rétention en énergie nette apparente (ANER). Les performances de croissance n'ont pas été significativement différentes $(P>0,05)$ entre les régimes A, B et C (rapport CHO/LIP variant de 4,95 à 2,06). En revanche, la diminution du rapport CHO/LIP à 1,38 (régime $\mathrm{D}$ ) a diminué le taux de croissance et l'efficacité alimentaire ; une diminution plus importante jusqu'à 0,94 (régime E) n'a pas eu d'effet plus notable $(P>0,05)$. L'indice hépatosomatique (HSI) a augmenté avec la décroissance du rapport $\mathrm{CHO} / \mathrm{LIP}$ et a atteint un maximum $(1,81)$ avec une valeur de $\mathrm{CHO} / \mathrm{LIP}$ égale à 0,94 et un minimum $(1,33)$ avec une valeur de 4,95. Aucune différence significative $(P>0,05)$ n'a été observée entre les régimes $\mathrm{B}, \mathrm{C}$ et $\mathrm{D}(\mathrm{CHO} / \mathrm{LIP}$ variant de 3,33 à 1,38$)$ pour les valeurs de HSI. Les teneurs corporelles en eau et en protéines ont été diminuées alors que celles en gras et en cendres ont augmenté avec la diminution du rapport CHO/LIP $(P<0,05)$. En revanche, la teneur en énergie brute n'a pas été affectée $(P>0,05)$. Les résultats de l'étude montrent que le rapport CHO/LIP optimal pour une croissance maximale du tilapia (Oreochromis niloticus) se situe entre 2,06 et 4,95.

Oreochromis niloticus / glucide/ lipide / alimentation / performance de croissance / composition corporelle

\section{INTRODUCTION}

Protein is the single most expensive ingredient in fish diets. The fact that high levels of dietary protein may lead to the consumption of protein for energy purposes, has led to the investigation of the use of nonprotein energy sources in fish diets [12-14]. Providing adequate energy from carbohydrates and lipids in fish diets can minimize the use of costly protein. The utilization of carbohydrates and lipids by fish is species specific. Although lipids are well utilized by most fish, excessive levels may reduce fish growth or produce fatty fish [11, $16,36]$. On the contrary, lipid deficient diets may result in growth retardation and other physiological symptoms $[10,36]$. No specific dietary requirement for carbohydrates has been demonstrated in fish [24]. An appropriate level of carbohydrates in fish diets is, however, required to avoid any disproportionate catabolism of proteins and lipids for the supply of energy and metabolic intermediates $[35,38]$.
The carbohydrate to lipid (CHO/LIP) ratio in fish diets has been investigated by a number of authors. Palmer and Ryman [26] suggested that there may be an optimum carbohydrate to lipid ratio value in trout diets which could maximize the metabolism of glucose through hepatic glycolysis and the overall efficiency of glucose use. Acceptable carbohydrate to lipid ratios for channel catfish diets have been reported to be between 0.45 and 4.5 [16]. Bieber-Wlaschny and Pfeffer [5] observed a better growth rate and enhanced protein and energy retention in rainbow trout (Salmo gairdneri R.) when the diets consisted of both fat and starch as compared to diets containing either only fat or starch. El-Sayed and Garling [13] reported that Tilapia zillii can efficiently utilize both carbohydrates and lipids as energy sources and that these can be substituted at a rate of $1 / 2.25$ commensurate with their physiological fuel values. Nematipour et al. [25] reported that hybrid stripped bass efficiently utilize both carbohydrates and lipids as energy sources but 
suggested that lipids be partially replaced with carbohydrates to improve fish quality and productivity. Erfanullah and Jafri [15] observed that the growth of walking catfish (Clarias batrachus) fed diets containing varying CHO/LIP ratios (0.02 to 43.00$)$ differs significantly.

Limited information is available on the optimal level of CHO/LIP ratio in the diets of Oreochromis niloticus. Shimeno et al. [33] studied the metabolic response of dietary carbohydrate to lipid ratios in Oreochromis niloticus. They reported that fish growth performance and protein sparing effects are elevated with an increase in dietary carbohydrate to lipid ratios. The present study was therefore conducted to determine the optimum carbohydrate to lipid ratio in practical diets of Oreochromis niloticus fingerlings.

\section{MATERIALS AND METHODS}

Oreochromis niloticus fingerlings with an average weight of $10.29 \pm 0.33 \mathrm{~g}$ were collected from the fish hatchery of the King Abdulaziz City for Science and Technology (KACST) Deerab, Riyadh. The fish were acclimatized to the experimental conditions for a period of two weeks before the start of the actual experiment. During this period, they were kept on the same standard diet as fed previously at the hatchery. Thirty randomly captured fish (divided into three replicates of 10 fish each) were killed immediately. After recording their body weight and length, they were stored at $-30{ }^{\circ} \mathrm{C}$ until determination of their initial body composition at a later stage [3]. One hundred and fifty fish were then randomly divided into 5 different groups with 3 replicates containing 10 fish in each replicate. The fish were kept in glass tanks $(100 \times 42.5 \times 50.0 \mathrm{~cm})$ containing dechlorinated and well aerated tap water and fitted with a waste filtration facility. The water temperature was maintained at $28 \pm 1{ }^{\circ} \mathrm{C}$ with the help of a thermostatically controlled heating system. Compressed air was used to maintain the oxygen supply. Regular monitoring of water quality parameters was carried out. These values ranged from $7.1-8.0$ for $\mathrm{pH}$, 5.6-6.7 $\mathrm{mg} \cdot \mathrm{L}^{-1}$ for dissolved oxygen, $0.12-0.20 \mathrm{mg} \cdot \mathrm{L}^{-1}$ for ammonia nitrogen, $0.33-0.58 \mathrm{mg} \cdot \mathrm{L}^{-1}$ for nitrite nitrogen and $235-350 \mathrm{mg} \cdot \mathrm{L}^{-1}$ for alkalinity as $\mathrm{CaCO}_{3}$.

Five isonitrogenous and isoenergetic diets containing different levels of carbohydrates and lipids were prepared using a pellet press with a $2 \mathrm{~mm}$ die (Tab. I). The maize grain was used as a source of carbohydrate. It was replaced gradually with equal amounts of corn oil and cod-liver oil on an energy equivalent basis. $\alpha$-cellulose was added to balance the diet composition. The diets were dried at $60{ }^{\circ} \mathrm{C}$ and then stored at $-18{ }^{\circ} \mathrm{C}$ throughout the experimental period. The proximate chemical compositions of the diets are given in Table II. The gross energy contents of the diets were calculated on the basis of their protein, fat and carbohydrate (NFE) contents using the equivalents of 23.64, 39.54, and $17.15 \mathrm{MJ} \cdot \mathrm{kg}^{-1}$ respectively [21]. Each diet was fed ad libitum to 3 replicates in a completely randomized design, twice daily for a period of 63 days. Daily feed intake and fortnightly weight gains were recorded. In order to quantify the exact amount of feed intake any feed refusal was siphoned out immediately, dried and weighed. The experiment was conducted under artificial light with a light and dark cycle of 12:12 hours. At the end of the experimental period all the fish were killed and their body weights and lengths were recorded. Five fish from each tank were dissected and their livers were removed and weighed. To determine the whole body composition, the rest of the fish from each tank were cut into pieces, minced, homogenized and immediately frozen at $-30{ }^{\circ} \mathrm{C}$ for further analysis. The proximate chemical composition was determined according to AOAC methods [3]. The gross energy (GE) contents of the fish were calculated from the fat and protein contents using the equivalents of $39.54 \mathrm{MJ} \cdot \mathrm{kg}^{-1}$ crude fat and $23.64 \mathrm{MJ} \cdot \mathrm{kg}^{-1}$ crude protein [21]. 
Table I. Composition of the experimental diets (\%).

\begin{tabular}{lrrrrr}
\hline Ingredients & \multicolumn{5}{c}{ Diets } \\
\cline { 2 - 6 } & \multicolumn{1}{c}{$\mathrm{A}$} & $\mathrm{B}$ & $\mathrm{C}$ & $\mathrm{D}$ & \multicolumn{1}{c}{$\mathrm{E}$} \\
\hline Fish meal & 45.00 & 45.50 & 46.00 & 46.50 & 47.00 \\
Wheat bran & 13.00 & 13.00 & 13.00 & 13.00 & 13.00 \\
Maize grain & 35.00 & 28.00 & 21.00 & 14.00 & 7.00 \\
Cod liver oil & 1.50 & 3.00 & 4.50 & 6.00 & 7.50 \\
Corn oil & 1.50 & 3.00 & 4.50 & 6.00 & 7.50 \\
Gelatin & 1.00 & 1.00 & 1.00 & 1.00 & 1.00 \\
C-Cellulose $_{\text {Mineral mixture }}^{1}$ & 0.00 & 3.50 & 7.00 & 10.50 & 14.00 \\
Vitamin mixture $^{2}$ & 2.00 & 2.00 & 2.00 & 2.00 & 2.00 \\
Total & 1.00 & 1.00 & 1.00 & 1.00 & 1.00 \\
& 100.00 & 100.00 & 100.00 & 100.00 & 100.00 \\
\hline
\end{tabular}

${ }^{1}$ One kg of the premix contained: $\mathrm{CaHPO}_{4}, 530 \mathrm{~g} ; \mathrm{K}_{2} \mathrm{HPO}_{4}, 80 \mathrm{~g} ; \mathrm{Na}_{2} \mathrm{HPO}_{4} 90 \mathrm{~g} ; \mathrm{MgCl}_{2} .6 \mathrm{H}_{2} \mathrm{O}, 100 \mathrm{~g} ; \mathrm{KCl}$, $67.5 \mathrm{~g} ; \mathrm{K}_{2} \mathrm{SO}_{4}, 80 \mathrm{~g} ; \mathrm{NaCl}, 30 \mathrm{~g} ; \mathrm{KI}, 0.05 \mathrm{~g} ; \mathrm{ZnSO}_{4} .7 \mathrm{H}_{2} \mathrm{O}, 2.5 \mathrm{~g} ; \mathrm{SeO}_{2}, 0.03 \mathrm{~g} ; \mathrm{CuSO}_{4} .5 \mathrm{H}_{2} \mathrm{O}, 0.15 \mathrm{~g} ; \mathrm{FeSO}_{4} .7 \mathrm{H}_{2} \mathrm{O}$, $18 \mathrm{~g} ;\left(\mathrm{NH}_{4}\right)_{6} \mathrm{Mo}_{7} \mathrm{O}_{24} \cdot 4 \mathrm{H}_{2} \mathrm{O}, 0.01 \mathrm{~g} ; \mathrm{MnSO}_{4} \cdot \mathrm{H}_{2} \mathrm{O}, 0.5 \mathrm{~g} ; \mathrm{NaF}, 1.2 \mathrm{~g} ; \mathrm{CoCl}_{2} \cdot 6 \mathrm{H}_{2} \mathrm{O}, 0.01 \mathrm{~g}$.

2 One kg of the premix contained: Vitamin A, $400000 \mathrm{IU} ; \mathrm{D}_{3}, 200000 \mathrm{IU} ; \mathrm{E}, 5000 \mathrm{IU} ; \mathrm{K}_{3}, 1 \mathrm{~g} ; \mathrm{B}_{1}, 1 \mathrm{~g}$; $\mathrm{B}_{2}, 1.5 \mathrm{~g} ; \mathrm{B}_{6}, 1 \mathrm{~g}$; Pantothenic acid, $5 \mathrm{~g}$; Niacin, $3 \mathrm{~g}$; Folic acid, $0.5 \mathrm{~g} ; \mathrm{B}_{12}, 2 \mathrm{mg}$; Biotin, $100 \mathrm{mg}$; Vitamin C, $20 \mathrm{~g}$.

Table II. Proximate chemical composition of fish diets (on \% dry matter basis).

\begin{tabular}{|c|c|c|c|c|c|}
\hline \multirow[t]{2}{*}{ Parameters } & \multicolumn{5}{|c|}{ Diets } \\
\hline & A & B & $\mathrm{C}$ & $\mathrm{D}$ & $\mathrm{E}$ \\
\hline Dry matter (\%) & 91.68 & 91.83 & 92.01 & 91.82 & 92.19 \\
\hline Crude protein & 38.02 & 37.96 & 38.12 & 37.83 & 37.24 \\
\hline Crude fibre & 2.19 & 4.78 & 8.05 & 11.23 & 14.12 \\
\hline Total fat & 8.14 & 10.56 & 14.01 & 16.84 & 19.53 \\
\hline Ash & 11.38 & 11.51 & 10.90 & 10.84 & 10.74 \\
\hline Nitrogen free extract (NFE) & 40.27 & 35.19 & 28.92 & 23.26 & 18.37 \\
\hline Gross energy $\left(\mathrm{MJ} \cdot \mathrm{kg}^{-1}\right)$ & 19.12 & 19.18 & 19.50 & 19.58 & 19.66 \\
\hline $\mathrm{CP} / \mathrm{CHO} / \mathrm{LIP}$ ratio $^{1}$ & $47 / 36 / 17$ & $47 / 31 / 22$ & $47 / 25 / 28$ & $46 / 20 / 34$ & $46 / 15 / 39$ \\
\hline $\mathrm{CHO} / \mathrm{LIP}$ ratio $^{2}$ & 4.95 & 3.33 & 2.06 & 1.38 & 0.94 \\
\hline $\mathrm{P} / \mathrm{E}$ ratio $\left(\mathrm{g} \text { protein } \cdot \mathrm{MJ}^{-1}\right)^{3}$ & 19.88 & 19.79 & 19.55 & 19.32 & 18.94 \\
\hline
\end{tabular}

${ }^{1}$ Proportionate gross energy ratio from crude protein, carbohydrates and lipids.

${ }^{2}$ Carbohydrate to lipid ratio on a weight basis.

${ }^{3}$ Crude protein to gross energy ratio.

Feed conversion ratio (FCR), specific growth rate (SGR), protein efficiency ratio (PER), net protein retention (NPR), apparent net energy retention (ANER) and hepatosomatic index (HSI) were calculated as follows:
- Feed conversion ratio $=\mathrm{kg}$ dry feed consumed per kg wet weight gain.

- Specific growth rate (as percentage of body weight gain per day) $=100$ [ln final wt. (g) - ln initial weight (g)] / time (days). 
- Protein efficiency ratio = liveweight gain $(\mathrm{g}) /$ protein consumed $(\mathrm{g})$.

- Net protein retention $=[$ increase in carcass protein / protein fed $] \times 100$.

- Apparent net energy retention (ANER = [(final body $\mathrm{GE} \mathrm{KJ} \cdot \mathrm{g}^{-1}$ ) - (initial body GE $\mathrm{KJ} \cdot \mathrm{g}^{-1}$ ) / KJ GE fed ] × 100).

- Hepatosomatic index $=($ liver weight $/$ fish weight) $\times 100$.

The condition factor $(\mathrm{k})$ was calculated according to the equation $\mathrm{k}=[\mathrm{W}(\mathrm{g}) /$ $\left.\mathrm{L}(\mathrm{cm})^{3}\right] \times 100$, where $\mathrm{W}$ is the wet weight of fish in grams and L is the length in centimeters. The results were subjected to statistical analysis using the analysis of variance technique and the means were compared by the Fisher LSD test according to Snedecor and Cochran [34]. A second order polynomial model (quadratic-linear model) was used to determine the optimal $\mathrm{CHO} / \mathrm{LIP}$ ratio for the maximum growth of the fish [7]. The model used was:

$$
\begin{gathered}
\mathrm{Y}_{\mathrm{i}}=\alpha+\beta_{1} \mathrm{x}_{\mathrm{i}}+\beta_{2} \mathrm{x}_{\mathrm{i}}^{2}+\varepsilon_{\mathrm{i}}, \\
\mathrm{i}=1,2,3 \ldots \ldots, \mathrm{n}
\end{gathered}
$$

where $\varepsilon_{i} \sim N\left(0, \sigma^{2}\right)$.

\section{RESULTS}

Significant differences $(P<0.05)$ were observed for the body weight gain of fish fed different CHO/LIP ratios (Tab. III). No significant differences $(P>0.05)$ were observed for the body weight gain of fish fed diets $\mathrm{A}, \mathrm{B}$ and $\mathrm{C}$ with $\mathrm{CHO} / \mathrm{LIP}$ ratios ranging from 4.95 to 2.06. Decreasing the carbohydrate to lipid ratio to 1.38 (diet D) significantly reduced $(P<0.05)$ the body weight gain in fish. A further decrease in the $\mathrm{CHO} / \mathrm{LIP}$ ratio to 0.94 (diet E), however, did not reduce $(P>0.05)$ the body weight gain any more. Similar trends were observed for the specific growth rate and condition factor. The relationship between body weight gain and carbohydrate to lipid ratios, determined using the second order polynomial model, is shown in Figure 1. Although the optimal dietary $\mathrm{CHO} / \mathrm{LIP}$ ratio for the maximum growth performance of fish ranged from 2.06 to 4.95 , the maximum weight gain appeared to be at a dietary $\mathrm{CHO} / \mathrm{LIP}$ ratio of 3.4. No fish mortality was observed during the whole experimental period. Similarly, no visual abnormalities were seen in fish livers.

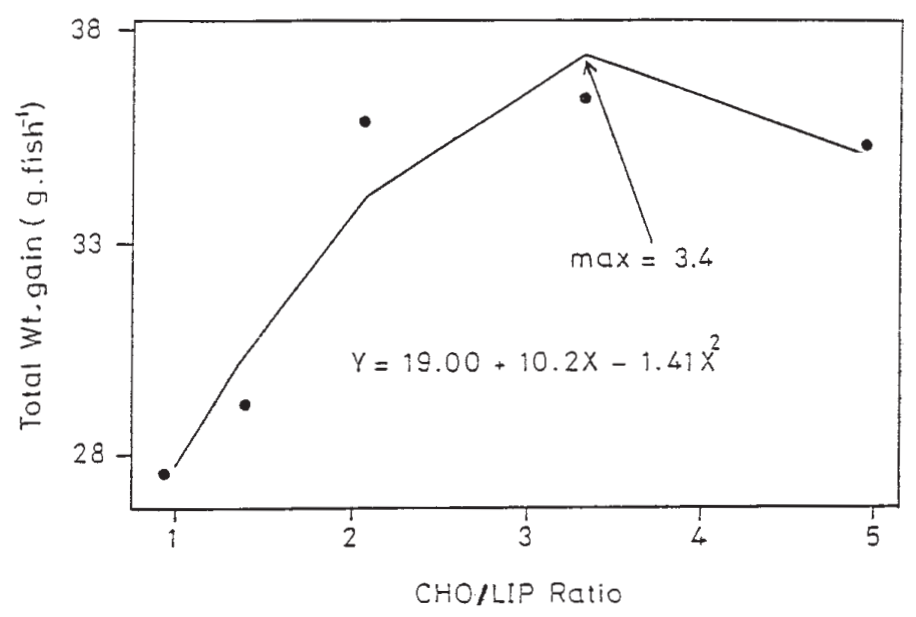

Figure 1. Relationship between CHO/LIP ratio and body weight gain. 
The hepatosomatic index value increased with the decrease in the $\mathrm{CHO} / \mathrm{LIP}$ ratios and was the highest (1.81) with a CHO/LIP ratio of 0.94 and lowest (1.33) with a CHO/LIP ratio of 4.95 (Tab. III). The fish fed diets $\mathrm{B}, \mathrm{C}$ and $\mathrm{D}$ with $\mathrm{CHO} / \mathrm{LIP}$ ratios ranging from 3.33 to 1.38 did not show any difference $(P>0.05)$ in the HSI values. No significant differences $(P>0.05)$ were observed in the feed consumption of fish fed different $\mathrm{CHO} / \mathrm{LIP}$ ratios (Tab. III). The diets $\mathrm{A}, \mathrm{B}$ and $\mathrm{C}$ with $\mathrm{CHO} / \mathrm{LIP}$ ratios ranging from 4.95 to 2.06 did not result in any difference $(P>0.05)$ in their feed efficiency, protein and energy retention. Decreasing the $\mathrm{CHO} / \mathrm{LIP}$ ratios to 1.38 and 0.94 (diets $\mathrm{D}$ and $\mathrm{E}$ ) significantly depressed these values. Fish fed diets $\mathrm{A}, \mathrm{B}$ and $\mathrm{C}$ did not show any difference $(P>0.05)$ in their PER, NPR and ANER values. Similarly the differences between diets D and E with CHO/LIP ratios of 1.38 and 0.94 respectively were not significant $(P>0.05)$.

The body composition of the fish was significantly affected $(P<0.05)$ by dietary $\mathrm{CHO} / \mathrm{LIP}$ ratios (Tab. IV). The differences among diets $\mathrm{A}, \mathrm{B}$ and $\mathrm{C}$ were, however, non significant $(P>0.05)$. Similarly, the diets $\mathrm{D}$ and $\mathrm{E}$ did not lead to any difference $(P>0.05)$ in the proximate composition of fish. Body moisture and crude protein contents decreased whereas fat and ash contents increased with a decrease in dietary CHO/LIP ratios. No significant $(P>0.05)$ differences were observed for gross energy retention.

\section{DISCUSSION}

The overall total feed consumption by Oreochromis niloticus was not affected by the variability in $\mathrm{CHO} / \mathrm{LIP}$ ratios. This indicated that both carbohydrates and lipids were equally acceptable by fish within the levels used on an energy equivalent basis in this experiment. As far as the carbohydrate and lipid levels in fish diets are concerned, our results were in close agreement with the findings of Teshima et al. [37] who concluded that Tilapia nilotica fingerlings grew optimally with diets containing $30-40 \%$ proteins, $12-15 \%$ lipids and $30-40 \%$ digestible

Table III. Growth performance of Oreochromis niloticus fed different levels of carbohydrates and lipids.

\begin{tabular}{|c|c|c|c|c|c|c|}
\hline \multirow[t]{2}{*}{ Parameters } & \multicolumn{6}{|c|}{ Diets } \\
\hline & A & B & $\mathrm{C}$ & $\mathrm{D}$ & $\mathrm{E}$ & S.E. ${ }^{1}$ \\
\hline Initial weight $\left(\mathrm{g} \cdot \mathrm{fish}^{-1}\right)$ & 10.26 & 10.43 & 10.19 & 10.38 & 10.21 & 0.33 \\
\hline Final weight $\left(\mathrm{g} \cdot \mathrm{fish}^{-1}\right)$ & $45.55^{\mathrm{a}}$ & $46.81^{\mathrm{a}}$ & $46.04^{\mathrm{a}}$ & $39.55^{\mathrm{b}}$ & $38.74^{\mathrm{b}}$ & 1.07 \\
\hline Total weight gain $\left(\mathrm{g} \cdot \mathrm{fish}^{-1}\right)$ & $35.29^{\mathrm{a}}$ & $36.38^{\mathrm{a}}$ & $35.85^{\mathrm{a}}$ & $29.17^{b}$ & $28.53^{\mathrm{b}}$ & 1.17 \\
\hline Specific growth rate (SGR) & $2.37^{\mathrm{a}}$ & $2.38^{\mathrm{a}}$ & $2.39^{\mathrm{a}}$ & $2.13^{\mathrm{b}}$ & $2.13^{\mathrm{b}}$ & 0.10 \\
\hline Condition factor $(\mathrm{k})$ & $2.98^{\mathrm{a}}$ & $3.06^{\mathrm{a}}$ & $2.95^{\mathrm{a}}$ & $2.70^{\mathrm{b}}$ & $2.60^{\mathrm{b}}$ & 0.21 \\
\hline Consumed feed dry matter $\left(\mathrm{g} \cdot \mathrm{fish}^{-1}\right)$ & 41.72 & 41.12 & 41.50 & 41.80 & 42.56 & 1.19 \\
\hline Feed conversion ratio (FCR) & $1.18^{\mathrm{a}}$ & $1.13^{\mathrm{a}}$ & $1.16^{\mathrm{a}}$ & $1.43^{b}$ & $1.49^{\mathrm{b}}$ & 0.11 \\
\hline Protein efficiency ration (PER) & $2.23^{\mathrm{a}}$ & $2.33^{\mathrm{a}}$ & $2.26^{\mathrm{a}}$ & $1.85^{\mathrm{b}}$ & $1.80^{\mathrm{b}}$ & 0.13 \\
\hline Net protein retention (NPR) & $34.99^{\mathrm{a}}$ & $36.45^{\mathrm{a}}$ & $35.15^{\mathrm{a}}$ & $27.26^{\mathrm{b}}$ & $26.56^{\mathrm{b}}$ & 1.31 \\
\hline $\mathrm{ANER}^{2}$ & $24.60^{\mathrm{a}}$ & $25.71^{\mathrm{a}}$ & $24.29^{\mathrm{a}}$ & $19.67^{b}$ & $18.91^{\mathrm{b}}$ & 0.96 \\
\hline Hepatosomatic Index (HSI) & $1.33^{\mathrm{c}}$ & $1.59^{\mathrm{b}}$ & $1.69^{\mathrm{b}}$ & $1.62^{\mathrm{b}}$ & $1.81^{\mathrm{a}}$ & 0.18 \\
\hline
\end{tabular}

${ }^{1}$ Pooled standard error.

2 Apparent net energy retention value.

a,b,c,d Different superscripts in the same row mean significant differences between the values at $5 \%$. 
Table IV. Body composition of Oreochromis niloticus fed different levels of carbohydrates and lipids (on $\%$ wet basis) ${ }^{1}$.

\begin{tabular}{|c|c|c|c|c|c|c|}
\hline \multirow[t]{2}{*}{ Parameters } & \multicolumn{6}{|c|}{ Diets } \\
\hline & A & B & $\mathrm{C}$ & $\mathrm{D}$ & $\mathrm{E}$ & S.E. ${ }^{2}$ \\
\hline Moisture (\%) & $74.57^{\mathrm{a}}$ & $74.72^{\mathrm{a}}$ & $74.39^{\mathrm{a}}$ & $73.95^{\mathrm{b}}$ & $73.53^{\mathrm{b}}$ & 0.66 \\
\hline Crude protein & $15.69^{\mathrm{a}}$ & $15.64^{\mathrm{a}}$ & $15.52^{\mathrm{a}}$ & $14.99^{\mathrm{b}}$ & $14.96^{\mathrm{b}}$ & 0.28 \\
\hline Total fat & $4.70^{\mathrm{b}}$ & $4.76^{\mathrm{b}}$ & $4.65^{b}$ & $5.04^{\mathrm{a}}$ & $5.11^{\mathrm{a}}$ & 0.14 \\
\hline Ash & $4.65^{\mathrm{b}}$ & $4.73^{b}$ & $4.70^{\mathrm{b}}$ & $5.01^{\mathrm{a}}$ & $5.13^{\mathrm{a}}$ & 0.16 \\
\hline Gross energy $\left(\mathrm{MJ} \cdot \mathrm{kg}^{-1}\right)$ & 5.56 & 5.57 & 5.50 & 5.53 & 5.55 & 0.11 \\
\hline
\end{tabular}

${ }^{1}$ Composition of fish slaughtered at the beginning of the experiment (moisture, $73.25 \%$; crude protein, $15.62 \%$; fat, $4.75 \%$; ash, $5.13 \%$ and gross energy, $5.56 \mathrm{MJ} \cdot \mathrm{kg}^{-1}$ ).

2 Pooled standard error.

a,b,c,d Different superscripts in the same row mean significant differences between the values at $5 \%$.

carbohydrates. El-Sayed and Garling [13] did not observe any significant difference in the performance of $T$. zillii over a wide range of $\mathrm{CHO} / \mathrm{LIP}$ ratios (8.76-0.81). They suggested that $T$. zillii can possibly utilize dietary lipids as an energy source more efficiently than carbohydrates. Our results neither support such a wide range of CHO/LIP ratios in the diets for $O$. niloticus nor confirm their hypothesis that dietary lipids are more efficiently utilized as an energy source than carbohydrates. The levels of dietary carbohydrates and lipids used by El-Sayed and Garling [13] in their experiment ranged from $12.0-36.8 \%$ and $4.2-14.8 \%$ respectively. The results of the present study indicate that the performance of $O$. niloticus was only significantly affected when the level of lipids in the diets increased beyond $14 \%$. Nematipour et al. [25] did not also observe any significant difference in the performance of hybrid stripped bass over a much wider range of carbohydrate to lipid ratios $(2.5$ to 16.8$)$. The reason may be the dietary levels of carbohydrates and lipids that ranges from $25-42 \%$ and $2.5-10 \%$ respectively.

The increase in FCR values with the decrease in the $\mathrm{CHO} / \mathrm{LIP}$ ratio indicates the poor utilization of diets when the dietary lipid level increases over 14\%. Similarly, the efficiency of protein and energy utilization decreased when the CHO/LIP ratio in the diets dropped to 1.38 and 0.94 . These results indicate that $O$. niloticus is capable of best utilizing lipids up to a level of $14 \%$ with a minimum level of carbohydrates (29\%) in their diets. Lowering the carbohydrate level beyond this limit with a simultaneous increase in lipid level, even on an energy equivalent basis, not only affected their growth performance but also the overall efficiency of energy and protein utilization. Fish fed low lipid high carbohydrate diets might metabolize less protein to meet their energy needs than fish fed high lipid low carbohydrate diets, resulting in higher dietary protein retention in tissues. The effect of cellulose, used as a filler to balance the energy content of the diets, cannot be ignored. Al-Ogaily [1] observed that $9 \%$ cellulose in the diets of $O$. niloticus improves the growth, and FCR, PER and NPR values. He, however, did not observe any negative effects of utilizing $12 \%$ cellulose in the diet. Anderson et al. [2], however, concluded that an increase in the level of cellulose above $10 \%$ is not desirable in the diets of $O$. niloticus. It has been observed that the elevated crude fiber content in fish diets may exert a negative effect on the 
digestibility of nutrients [20]. Our results are in line with these findings since the diet that produced the best results in the present study contained $10.5 \%$ cellulose.

The negative effect of larger amounts of dietary lipids (at low levels of carbohydrate supply) could be explained in relation to a higher metabolic demand for glucose that necessitates increased gluconeogenesis. Shimeno et al. [33] suggested that carbohydrates accelerate glycolysis and lipogenesis and decrease gluconeogenesis and amino acid degradation in the liver. This metabolic response seems to explain the high ability of $O$. niloticus to utilize dietary carbohydrates and their protein sparing effect. These results are in line with the earlier findings of Anderson et al. [2] and Qadri and Jameel [27] who reported that the growth performance and feed utilization in young Oreochromis niloticus was enhanced by progressive levels (up to $40 \%$ ) of various carbohydrates in the diets. The results of the present study indicate that $O$. niloticus can utilize carbohydrates more efficiently than lipids. Chou and Shiau [11] reported that the optimal dietary lipid for the maximum growth of hybrid Tilapia $(O$. niloticus $\times$ O. aureus) is about $12 \%$. They suggested that Tilapia do not utilize the additional energy provided by the supplementary dietary lipid (over 5\%) for growth. Similar observations were made by Seenapa and Devaraj [30] who reported that fingerlings of Catla catla (Ham.) which is another herbivorous fish, efficiently utilize carbohydrates up to $35 \%$ but show poor growth on diets with dietary fat contents up to $12 \%$. The protein sparing effect was only observed with carbohydrates. Our results are also in line with the findings of Erfanullah and Jafri [15] who observed that the growth of walking catfish (Clarias batrachus) fed diets containing varying $\mathrm{CHO} / \mathrm{LIP}$ ratios $(0.02$ to 43.00) differed significantly. They reported that the highest weight gain, SGR, FCR, PER, NPR and energy retention values were observed in fish fed $27 \%$ dietary carbohydrates and $8 \%$ lipids corresponding to a $\mathrm{CHO} / \mathrm{LIP}$ ratio of 3.38 .

The hepatosomatic index (HSI) varies as a function of dietary protein, carbohydrate and lipid level [16, 19, 22, 31]. The present results indicate that the HSI values are only affected when the carbohydrate and lipid levels in the diets are increased over $35.19 \%$ and $16.84 \%$ respectively. Nematipour et al. [25] reported that the HSI values in hybrid stripped bass did not change when fed diets high in carbohydrates or lipids. On the contrary to our findings in $O$. niloticus, the HSI values in rainbow trout have been reported to increase with the rise in carbohydrate level (reflecting an increasing glycogen storage in the liver) whereas no change of a similar kind was observed in response to high dietary fat content $[5,6]$. This may be linked to the species difference, since warm water fish have been reported to utilize carbohydrates better than cold water fish [23].

The results on the body composition of fish appear to have a good correlation with growth performance. Both the endogenous and exogenous factors operate simultaneously to influence the body composition of fish [9, 17, 32]. Although the available dietary energy plays an important role in determining body lipid deposition, the dietary lipid content is regarded as the most important factor influencing carcass lipid in fish $[8,18,29]$. An increase in dietary lipid level elevates the body lipid level in $O$. niloticus. The increase in carcass lipids with increasing dietary lipids and the consequent reduction in carcass proteins have been reported for most species investigated [12]. The results of the present study indicate that the body moisture and crude protein contents decrease whereas the lipid and ash contents increase with a decrease in $\mathrm{CHO} / \mathrm{LIP}$ ratio. The use of lipids as a source of dietary energy frequently contributes to the formation of higher fat reserves $[4,28]$. The results of the present study suggest that the optimum dietary $\mathrm{CHO} / \mathrm{LIP}$ ratio for the maximum growth performance of Oreochromis niloticus is between 2.06 and 4.95. 


\section{ACKNOWLEDGEMENTS}

We are thankful to the King Abdulaziz City for Science and Technology (KACST) for providing the fish and other facilities during the final write up of this manuscript.

\section{REFERENCES}

[1] Al-Ogaily S.M., Effect of feeding different levels of cellulose on the growth performance and body composition of Oreochromis niloticus, Arab Gulf J. Scient. Res. 14 (1996) 731-745.

[2] Anderson J., Jackson A.J., Matty A.J., Capper B.S., Effect of dietary carbohydrate and fibre on the tilapia Oreochromis niloticus (Lin.) Aquaculture 37 (1984) 303-314.

[3] Association of Official Analytical Chemists Official Methods of Analysis, 14th ed., Washington DC, 1984.

[4] Bergot F., Carbohydrate in rainbow trout diet: Effects of the level and source of the carbohy drate and the number of meals on the growth and body composition, Aquaculture 18 (1979) 157-167.

[5] Bieber-Wlaschny M., Pfeffer E., Gelatinized maize starch versus sunflower oil or beef tallow as sources of non protein energy in diets for rainbow trout (Salmo gairdneri R.) I. Growth rate and utilization of dietary energy and protein, J. Anim. Physiol. Anim. Nutr. 57 (1987) 150-156.

[6] Brauge C., Medale F., Corraze G., Effect of dietary carbohydrate levels on growth, body composition and glycaemia in rainbow trout, Oncorhynchus mykiss, reared in seawater, Aquaculture 123 (1994) 109-120.

[7] Brown D., Rothery P., Models in Biology: Mathematics, Statistics and Computing, John Wiley and Sons, Chichester, West Sussex, England 1994.

[8] Buckley J.T., Groves T.D.D., Influence of feed on the body composition of finfish, in: Halver J.E., Tiews K. (Eds.), Finfish Nutrition and Fishfeed Technology, Vol. II., Heenemann Verlaggesellschaft, Berlin, Germany, 1979 pp. 335-344.

[9] Burtle G.J., Body composition of farm raised catfish can be controlled by attention to nutrition, Feedstuffs 62 (1990) 68-70.

[10] Castell J.D., Sinnhuber R.O., Lee D.J., Wales J.H., Essential fatty acids in the diet of rainbow trout (Salmo gaindneri), Physiological symptoms of EFA deficiency, J. Nutr. 102 (1972) 67-92.

[11] Chou B.S., Shiau S.Y., Optimal dietary lipid level for growth of juvenile hybrid tilapia, Ore ochromis niloticus $\times$ Oreochromis aureus, Aquaculture 143 (1996) 185-195.
[12] De Silva S.S., Guansekera R.M., Shim K.F., Interactions of varying dietary protein and lipid levels in young red tilapia: evidence of protein sparing, Aquaculture 95 (1991) 305-318.

[13] El-Sayed A.M., Garling D.L. Jr., Carbohydrate to lipid ratios in diets for Tilapia zillii fingerlings, Aquaculture 73 (1988) 157-163.

[14] Erfanullah Jafri A.K., Protein sparing effect of dietary carbohydrate in diets for fingerling Labeo rohita, Aquaculture 136 (1995) 331-339.

[15] Erfanullah Jafri A.K., Effect of dietary carbohydrate to lipid ratio on growth and body composition of walking catfish (Clarias batrachus), Aquaculture 161 (1998) 159-168.

[16] Garling D.L. Jr., Wilson R.P., Effects of dietary carbohydrate to lipid ratios on growth and body composition of fingerling channel catfish, Prog. Fish Cult. 39 (1977) 43-47.

[17] Haard N.F., Control of chemical composition and food quality attributes of cultured fish, Food Res. Int. 25 (1992) 289-307.

[18] Hanley F., Effects of feeding supplementary diets containing varying levels of lipid on growth, food conversion and body composition of Nile tilapia (Oreochromis niloticus L.), Aquaculture 93 (1991) 323-334.

[19] Hilton J.W., Atkinson J.L., Response of rainbow trout (Salmo gairdneri) to increased levels of available carbohydrate in practical trout diets, Brit. J. Nutr. 47 (1982) 597-607.

[20] Kirchgessener M., Kürzinger H., Schwarz F.J., Digestibility of crude nutrients in different feeds and estimation of their energy content for carp (Cyprinus carpio L.), Aquaculture 58 (1986) 185-194.

[21] Kleiber M., The Fire of Life. An introduction to animal energetics, John Wiley, New York, 1961.

[22] Lee D.J., Putnam G.B., The response of rainbow trout to varying protein / energy ratios in a test diet, J. Nutr. 103 (1973) 916-922.

[23] Lovell R.T., Nutrition of aquaculture species, J. Anim. Sci. 69 (1991) 4193-4200.

[24] National Research Council (NRC), Nutrient Requirements of Fish, National Academy Press, Washington DC, 1993.

[25] Nematipour G.R., Brown M.L., Galtin D.M III, Effects of dietary carbohydrate: lipid ratio on growth and body composition of hybrid stripped bass, J. World Aquaculture Soc. 23 (1992) 128-132.

[26] Palmer T.N., Ryman B.E., Studies on oral glucose intolerance in fish, J. Fish Biol. 4 (1972) 311-319.

[27] Qadri N.N., Jameel K., Effect of dietary carbohydrate of differing molecular complexity on tilapia (Sarotherodon mossambicus), Pak. J. Sci. Ind. Res. 32 (1989) 382-386. 
[28] Refstie T., Austreng E., Carbohydrate in rainbow trout diets. III. Growth and chemical composition of fish from different families fed four levels of carbohydrate in the diet, Aquaculture 25 (1981) 35-49.

[29] Sargent J., Henderson R.J., Tocher D.R., The lipids, in: Halver J.E. (Ed.), Fish Nutrition, Academic Press, New York, NY, 1989, pp. 154-209.

[30] Seenapa D., Devaraj K.V., Effect of different levels of protein, fat and carbohydrate on growth feed utilization and body carcass composition of fingerlings Catla catla (Ham.), in: Billard R., Gall G.A. (Eds.), The Carp, Proccedings of the Second International Symposium held in Budapest, Hungary, September 6-9, 1993, 129 (1995) 243-249.

[31] Serrano J.A., Nematipour G.R., Galtin D.M III, Dietary protein requirement of red drum (Sciaenops ocellatus) and relative use of dietary carbohydrate and lipid, Aquaculture 101 (1992) 283-293.

[32] Shearer K.D., Factors affecting the proximate composition of cultured fishes with emphasi on salmonids, Aquaculture 119 (1994) 63-88.
[33] Shimeno S., Ming D.C., Takeda M., Metabolic response to dietary carbohydrate to lipid ratios in Oreochromis niloticus, Nippon Suisan Gakkaishi 95 (1993) 827-833.

[34] Snedecor G.W., Cochran W.G., Statistical Methods, 8th ed., The Iowa State University Press, Ames, Iowa, 1989.

[35] Steffens W., Principles of Fish Nutrition, Ellis Horwood Limited, Publishers, Chichester, West Sussex, England, 1989.

[36] Takeuchi T., Satoh S., Watnabe T., Requirement of Tilapia nilotica for essential fatty acids Bull. Jpn. Soc. Sci. Fish. 49 (1983) 977-982.

[37] Teshima S., Kanzawa A., Uchiyama Y., Effects of dietary protein, lipid and digestible carbohydrate levels on the weight gain, feed conversion efficiency and protein efficiency ratio of Tilapia nilotica, Mem. Kagoshima Univ. Res. Center S. Pac. 6 (1985) 56-71.

[38] Wilson R.P., Utilization of carbohydrate by fish, Aquaculture 124 (1994) 67-80. 